\title{
EXPERIMENTAL HTLV-I INFECTION AND ASSOCIATED MYELOPATHY
}

\author{
CARLOS M. DE CASTRO COSTA*, EBERVAL G. DE FIGUEIREDO**, \\ TEREZINHA J.T. SANTOS***, CARINA H. FROTA****, CARMEN C.G. LOBO****, \\ FRANKLIN J.C. SANTOS ****, RAIMUNDO N. ALCANTARA****, RODRIGO S.N. RAMOS ${ }^{* * * *,}$ \\ TARCISIO T.S. ROCHA****, TRICIA F. NOGUEIRA****
}

\begin{abstract}
HTLV-I infection and associated myelopathy has been reproduced experimentally in vitro and in vivo and these studies have shown the possibility of creating several lines of infective cells and of detecting minor and major clinical expressions of HTLV-I associated myelopathy in rabbits and rats.
\end{abstract}

KEY WORDS: HTLV-I, infection, cell lines, myelopathy, rabbits, rats.

\section{Infecção e mielopatia experimentais associadas ao HTLV-I}

RESUMO - A infecção e mielopatia associada ao HTLV-I têm sido reproduzidas experimentalmente in vitro e in vivo e esses estudos têm evidenciado a possibilidade de criar várias linhas celulares infectivas e de detectar micro e macro-expressões clínicas de mielopatia associada ao HTLV-I em coelhos e ratos.

PALAVRAS-CHAVE: HTLV-I, infecção, linhas celulares, mielopatia, coelhos, ratos.

Since the discovery of the relationship of HTLV-I with the human pathologies adult T-cell leukemia (ATL) and tropical spastic paraparesis (TSP) or HTLV-I associated myelopathy (TSP/ HAM $)^{1,2}$, attempts have been made to reproduce this infectious condition experimentally in vitro and in vivo. This way it has been shown that HTLV-I transforms cell lines (lymphocytes) in humans ${ }^{3}$ and infects animals such as monkeys ${ }^{4-7}$, cats $^{8}$, rabbits ${ }^{9-13}$, hamsters ${ }^{14,15}$, rats and mice ${ }^{16-20}$.

These experimental studies then became concerned with the cellular reproduction of the HTLVI related pathological conditions and/or their clinical expression (ATL or TSP/HAM).

Several HTLV-I producing cell lines were built up: Tateno et al. ${ }^{16}$ developed the TARS-1, TARS-2 and TART-1 lines that produce type C retrovirus (HTLV) and antigens associated with ATL. Akagi et al. ${ }^{21}$ infected rabbits with MT2 cells (human HTLV producing cells) which expressed antibodies to HTLV. The lymphocytes taken out between four and 14 days after inoculation could be immortalized in vitro and expressed AT2 and viral particles of type C. Eguchi et al. ${ }^{15}$ have shown the development of tumors (lymphomas) by transplanting lymphoid cells of Syrian hamsters HCT-2. Seto et al. ${ }^{11}$ developed the cell line F647a of infected rabbit and succeeded in inducing cellular ATL in rabbits without, however, clinical signs. Cockerell et al. ${ }^{13}$ inoculated rabbits with Ra-1 cells

Service of Neurology (Hospital University) / Laboratory of Experimental Neurology (Department of Physiology and Pharmacology), Federal University of Ceará (UFC), Brazil: *MD, MsC, PhD; **MD; ***Pharmacist, MsC; ****Student. Aceite: 6-março-1998.

Dr. Carlos Maurício de Castro Costa - Laboratório de Neurologia Experimental e Neurofisiologia - Departamento de Fisiologia e Farmacologia/UFC - Rua Cel. Nunes de Melo 1127 - 60430-270 Fortaleza CE - Brasil FAX 55852439333 / 2434256. 
(transformed cells of HTLV-I infected rabbits), which showed serological positivity without, however, clinical signs. Suga et al. ${ }^{22}$ developed an HTLV-I animal model with inoculation of MT2 cells without clinical signs. Fan et al. ${ }^{23}$ reported on the development of cell-free infection assay for HTLV-I. Lairmore et al. ${ }^{24}$ infected rabbits with different strains of HTLV-I containing cells and concluded that there exists a heterogeneity in the biological response to HTLV-I infection. Akagi et al. ${ }^{25}$ succeeded to experimentally infect different kinds of human nerve cells with HTLV-I, thus showing that this retrovirus may have a wide spectrum of infectivity in human nervous tissue. Ibrahim et al. ${ }^{26}$ reported on the more expressive susceptibility of Fischer F344 and Brown Norway rats strains to HTLV-I infection, as compared with the low expression of Lewis and BB rat strains. Moreover, they have shown that HTLV-I infection occurs in adult rats but is suppressed with time.

The availability of transgenic models has been an important step for pathogenetic studies ${ }^{17-20}$. The main tax transgenic mouse models include HTLV-LTR, MMTL-LTR, Ig/SV40, Ig, Thy 1.2 and $\mathrm{G} 2 \mathrm{mB}$ enhancers, and tax, Env pX, pX and c-myc transgenes. They have tissue expression in muscle, bladder, bone, sallivary glands, brain, thymus, stomach and muscle (HTLV-LTR tax / Env pX), with development of neurofibromas, bone abnormalities, exocrinopathy, growth retardation, thymic atrophy and early death; the HTLV-LTR $\rightarrow$ c-myc has expression in lymph nodes with development of $\mathrm{CD}^{+} \mathrm{CD}^{+} \mathrm{T}$-cell lymphomas and B-cell lymphomas ${ }^{19}$. However, these models have not induced TSP/HAM in animals. This fact may possibly be due to lack of the immune response directed against the transgene, to the absence of cofactors, or to genetic background ${ }^{18}$. These facts support the notion that TSP/HAM is a multifactorial syndrome, involved with different cofactors.

The results with clinical neurological expression of HTLV-I infection in animal models have been divulged by Minagawa et al. ${ }^{27}$, Ishiguro et al. ${ }^{28}$, Kushida et al. ${ }^{29,30}$ and De Castro-Costa ${ }^{31}$.

Minagawa et al. ${ }^{27}$ infected rabbits with two strains of HTLV-I, isolated respectively from a TSP/HAM patient from Colombia and from a seropositive asymptomatic blood donor. Out of these rabbits, six developed persistent infection and became seropositive. From four rabbits, intracerebroventricularly and intravenously inoculated, only one developed spasticity and hyperreflexia of the hindpaws six weeks after inoculation. The remaining three rabbits showed transient and nonprogressive or constant hyperreflexia.

Ishiguro et al. ${ }^{28}$ inoculated rats with MT2 cells and the transmission occurred in more than $80 \%$ of them, independently of strain and age. However, the positive serology was different with these variables. The inoculated newborn rats remained seronegative, whereas the adult rats inoculated 16 weeks after birth became seropositive. According to the titer of antibodies the authors classified the animals as high (AC1, F344 and SDJ), intermediate (WKA, BUF and LEJ) and low (LEW) responders. Three out of sixteen WKA seronegative rats developed spastic paraparesis of the hindpaws. Histopathologically these animals showed spinal lesions with loss of myelin and axon in the lateral and anterior funiculi and macrophage infiltration predominating in the dorsal cord as well as the cervical and lumbar region.

Kushida et al. ${ }^{29}$ intravenously inoculated female adult WKA rats with Ra-1 and MT2 cells. From two WKA rats inoculated with Ra-1 cells at the age of four weeks, one developed HAM 27 months post-inoculation; from eight WKA rats inoculated with MT2 cells at the age of three weeks, three developed HAM 20 months after inoculation; however, from eight F344 rats inoculated with MT2 cells at the age of four weeks, none developed HAM. The HAM rats showed histopathologically a symmetrical degeneration of the white matter with mononuclear (macrophage) infiltration of the cervico-thoracic spinal cord and a degeneration of peripheral nerves and roots. The HAM rats were serologically positive. Kushida et al. ${ }^{30}$ reported a high incidence of HAM symptoms in WKA rats inoculated with MT2 cells, while the F344 rats did not develop any symptoms. From eight WKA rats, six (75\%) developed HAM between 82-118 weeks after inoculation presenting clinical spasticity, atrophy, tremor and progressive course. One of the rats developed a subcutaneous tumor. From two WKA rats inoculated with Ra-1 cells, only one developed HAM 120 weeks after inoculation. 
De Castro-Costa ${ }^{31}$ inoculated 18 Wistar rats with full blood of two TSP/HAM patients from Brazil and observed them clinically and behaviorally for eight months until they spontaneously died. From these parent rats, siblings were born of which 12 were observed for 15 months. The results showed a significant decrease $(\mathrm{p}<0.01)$ in the motor capacities and behaviors of the parent and sibling rats (minor changes) as well as the presence of spastic paraparesis (major changes) in two of the sibling rats, which were serologically negative.

Both cellular and clinical studies confirm the reproducibility of the HTLV-I infection and HAM. However, as for the clinical studies, most of the animals that exhibited paralysis were old rats (aging from 15 to 32 months), since rats have an average life span of 24 months ( 2 years $)^{32}$. This differs from the human cases who have a mean age of 40 years and so are comparatively younger than the animals; possibly, as preliminarily shown by De Castro-Costa ${ }^{31}$, minor motor changes should exist from the early phases of evolution suggesting that more investigations should be carried out in order to offer more accurate clinical studies as well as stepwise follow-up of the pathological lesions. This may contribute to a better understanding of the long-term studies of the pathogenetic mechanisms of TSP/HAM. Moreover, studies of siblings from HTLV-I infected rats may represent a more natural model for experimental TSP/HAM studies.

\section{REFERENCES}

1. Gessain A, Barin F, Vernant JC, et al. Antibodies to human T-lymphotropic virus type I in patients with tropical spastic paraparesis. Lancet 1985;2:407-409.

2. Osame M, Usuku K, Izumo S, et al. HTLV-I associated myelopathy: a new clinical entity. Lancet 1986;1:1031-1032.

3. Miyoshi I, Yoshimoto S, Kubonishi I, et al. Transformation of normal human cord lymphocytes by co-cultivation with a lethally irradiated human T-cell line carrying type C particles. Gann 1981;79:997.

4. Miyoshi I, Taguchi H, Fujishita M, et al. Transformation of monkey lymphocytes with adult T-cell leukemia virus. Lancet 1982;1:1016.

5. Gajdusek DC, Amyx HL, Gibbs CJ Jr, et al. Transmission experiments with human T-lymphotropic retroviruses and human AIDS tissue. Lancet 1984;1:1415-1416.

6. Kinoshita K, Yamanouchi K, Ikeda S, et al. Oral infection of a common marmoset with human T-cell leukemia virus type I (HTLV-I) by inoculating fresh human milk of HTLV-I carrier mothers. Jpn J Cancer Res (Gann) 1985;76:1147-1153.

7. Nakamura H, Hayami M, Ohta Y, et al. Protection of cynomolgus monkey against infection by human T-cell leukemia virus type I by immunization with viral Env gene products produced in Escherichia coli. Int J Cancer 1987;40:403-407.

8. Hoshino H, Tanaka H, Shimotohno K, et al. Immortalization of peripheral blood lymphocytes of cats by human T-cell leukemia virus. Int J Cancer 1984;34:513-517.

9. Miyoshi I, Yoshimoto S, Taguchi H, et al. Transformation of rabbit lymphocytes with adult T-cell leukemia virus. Jpn J Cancer Res (Gann) 1983;74:1-4.

10. Miyoshi I, Yoshimoto S, Kubonishi I, et al. Infectious transmission of human T-cell leukemia virus to rabbits. Int J Cancer 1985;35:81-85.

11. Seto A, Kawanishi M, Matsuda S, Ogawa S, Miyoshi I. Adult T-cell leukemia-like disease experimentally induced in rabbits. Jpn J Cancer Res (Gann) 1988;79:335-341.

12. Ogawa K, Matsuda S, Seto A. Induction of leukemia infiltration by allogeneic transfer of HTLV-I transformed T-cells in rabbits. Leukemia Res 1989;79:335-341.

13. Cockerell GL, Lairmore M, De B, Roznak J, Hartley TM, Miyoshi I. Persistent infection of rabbits with HTLV-I: patterns of anti-viral antibody reactivity and detection of virus gene amplification. Int J Cancer 1990;45:127-130.

14. Akagi T, Takata H, Ohtsuki Y, et al. Transformation of hamster spleen lymphocytes by human T-cell leukemia virus type I. Int J Cancer 1986;37:775-779.

15. Eguchi T, Kubonishi I, Daibata M, et al. Serial transplantation of an HTLV-I transformed lymphoid cell line into hamsters. Int J Cancer 1988;41:868-872.

16. Tateno M, Kondo N, Itoh T, Chubachi T, Togashi T, Yoshiki T. Rat lymphoid cell lines with human T-cell leukemia virus production. J Exp Med 1984;159:1105-1116.

17. Gonzalez-Dunia D, Grinber G, Briand P, Brahic M, Ozden S. Tissue expression pattern directed in transgenic mice by the LTR of an HTLV-I provirus isolated from a case of tropical spastic paraparesis. Virology 1992;187:705-710.

18. Ozden S, Coscoy L, Gonzalez-Dunia D. HTLV-1 transgenic models: an overview. J Acquir Immune Defic Syndr Hum Retrovirol 1996;13(Suppl):S154-S161.

19. Grossman WJ, Ratner L. Transgenic mouse models for HTLV-I infection. J Acquir Immune Defic Syndr Hum Retrovirol 1996;13(Suppl):S162-S169.

20. Nerenberg M, Xu X, Brown DA. Transgenic models of HLTV-I mediated disease and latency. Curr Top Microbiol Immunol 1996;206:175-196.

21. Akagi T, Takeda I, Oka T, Ohtsuki Y, Yano S, Miyoshi I. Experimental infection of rabbits with human T-cell leukemia virus type I. Jpn J Cancer Res (Gann) 1985;76:86-94. 
22. Suga T, Kameyama T, Kinoshita T, et al. Infection of rats with HTLV-I: a small animal model for HTLV-I carriers. Int J Cancer 1991;49:764-769.

23. Fan N, Gavalchin J, Paul B, Weels KH, Lane MJ, Poiesz BJ. Infection of peripheral blood mononuclear cells and cell lines by cell-free human T-cell lymphoma / leukemia virus type I. J Clin Microbiol 1992;30:905-910.

24. Lairmore MD, Roberts B, Frann D, Rovnah H, Weiser MG, Cockerell GL. Comparative biological responses of rabbits infected with human T-lymphotropic virus type I isolates from patients with lymphoproliferative and neurodegenerative disease. Int J Cancer 1992;50:124-130.

25. Akagi T, Hoshida Y, Yoshino T, et al. Infectivity of human T-lymphotropic virus type I to human nervous tissue cells in vitro. Acta Neuropathol (Berl) 1992;84:147-152.

26. Ibrahim F, Fiette L, Gessain A, Buisson N, De-Thé G, Bomford R. Infection of rats with human T-cell leukemia virus type I: susceptibility of inbred strains, antibody response and provirus location. Int J Cancer 1994;58:446-451.

27. Minagawa H, Mora CA, Asher DM, Stone GA, Liberski PP, Gibbs CJ. Transmission of human T-cell leukemia virus type I from a patient with HTLV-I associated myelopathy / tropical spastic paraparesis and an asymptomatic carrier to rabbits. Arch Virol 1991;118:235-245.

28. Ishiguro $\mathrm{H}$, Abe $\mathrm{M}$, Seto $\mathrm{K}$, et al. A rat model of human T-lymphocyte virus type I (HTLV-I) infection: 1 . Humoral antibody response, provirus integration, and HTLV-I associated myelopathy / tropical spastic paraparesis-like myelopathy in seronegative HTLV-I carrier rats. J Exp Med 1992;176:981-989.

29. Kushida S, Matsumura M, Tanaka H, et al. HTLV-I associated myelopathy / tropical spastic paraparesis-like rats by intravenous infection of HTLV-I producing rabbit or human T-cell line into adult WKA rats. Jpn J Cancer Res (Gann) 1993;84:831-833

30. Kushida S, Mizusawa H, Matsumura M, et al. High incidence of TSP/HAM-like symptoms in WKA rats after administration of human T-cell leukemia virus type I producing cells. J Virol 1994;68(11):7221-7226.

31. De Castro-Costa CM. A preliminary analysis of an experimental long-term study of motor behavior and clinical aspects of Wistar rats inoculated with blood from HTLV-I positive TSP patients from Ceará (Northeastern Brazil). In Zaninovic V (ed). HTLV - Truths and Questions. Cali: Feriva, 1996:89-95.

32. Adams RD, Victor M, Ropper AH. The neurology of aging. In Adams RD, Victor M. Principles of neurology. New York: McGraw-Hill, 1977:608-620. 